Dhaka Univ. J. Biol. Sci. 27(1): 101-111, 2018 (January)

\title{
A TAXONOMIC ACCOUNT OF PTERIDOPHYTIC FLORA OF ADAMPUR FOREST, MOULVIBAZAR DISTRICT, BANGLADESH
}

\author{
NADRA TABASSUM ${ }^{*}$ \\ Department of Botany, University of Dhaka, Dhaka-1000, Bangladesh
}

Key words: Taxonomic account, Pteridophytic flora, Adampur forest, Bangladesh

\begin{abstract}
A total of 17 pteridophyte species belonging to 11 genera and 9 families have been identified from Adampur forest of Moulvibazar district in Bangladesh are dealt with. Updated nomenclature with important synonyms, family name, English name, local name, citation of the specimen examined and a crisp description has been furnished under each species. Photographs of the species have been provided for easy identification. The voucher specimens have been deposited in the Dhaka University Salar Khan Herbarium, Department of Botany, University of Dhaka.
\end{abstract}

\section{Introduction}

Pteridophytes are widely distributed throughout the world. They show luxuriant growth from sea level to the highest mountains in moist and shady tropical and temperate forests ${ }^{(1)}$. From the evolutionary point of view, pteridophytes are quite important for their evolutionary trend of vascular system and portraying the succession of seed habitat in the plants. Besides, they established a link between the lower group of plant and advanced seed bearing plants and consequently pteridophytes have been placed between the bryophytes and higher vascular plants. Despite being the ancient plants their vegetation is under threat in dominance of seed bearing plants(2). Some species are very beneficial to humans and many species attracts plant lovers for their graceful, fascinating and beautiful foliage (3). Although pteridophytes including ferns have been neglected due to its less economic importance but since ancient time ferns are of human interest for medical value as well. It is widely used as a source of medicine in China, India and native America for a long time. In these circumstances, human interests for ferns and its allies will be not only ornamental but also medicinal plants(1).

The present day pteridophytes are mostly herbaceous plants distributed mostly to tropical and subtropical regions comprising about 12,500 ferns ${ }^{(1)}$. About 900 species of pteridophytes grow in the subcontinent of which about $50 \%$ are endemic. In Bangladesh, pteridophytes are represented by 250 species, of which 230 are ferns that grow either as epiphytes, mesophytes, lithophytes or hydrophytes ${ }^{(4,5)}$. Considering their traditional

*<nadra.tabassum@du.ac.bd>. 
medicinal and food value a very few studies have been carried out until now. Uddin et al. (1998) reported about 40 medicinal ferns and fern allies available in Bangladesh ${ }^{(6)}$. Recent study revealed 40 pteridophytic species having ethnobotanical uses in the areas of Chittagong hill tracts ${ }^{(7)}$. Sarker et al. (2009) reported 16 pteridophytes from Mymensingh along with their medicinal and food value( ${ }^{(8)}$. Besides various reports on uses of pteridophytes Hadiuzzaman et al. (1993) reported a new record of Salvinia auriculata in Bangladesh ${ }^{(9)}$. Despite there are fragmentary reports on the pteridophytic flora of different areas of the country studies on forest pteridophytic flora have not been conducted so far. Extensive survey of pteridophytic flora will help to conserve this important ancient land plants and for conservation of pteridophytes, a checklist is the first step to look forward.

Adampur forest is a hill reserve forest under the jurisdiction of Rajkandi Forest Range, at Kamalganj Upazila of Moulvibazar district (10). The forest bit has three forest blocks including Lewachara block, Daluachara block and Baghachara block. In Daluachara block most of the forest is natural and in Lewachara and Baghachara blocks some areas are newly planted. Our preliminary survey covered the Daluachara block of Rajkandi Bit. This area is comprised of dense forest and hillocks. A chara is running through the forest and some plantation program was observed. This tropical forest comprises an area of 13,080 acres and is situated southeast of Lawachara National Park. The Dhalai River flows adjacent to this forest. Numerous hillocks with water streams form part of the topography of Adampur. There are two-forest villages within this mixed evergreen forest. Rajkandi reserve forest situated in northeast area and the Bhanugach mountains are in west part of the Kamalganj Upazilla. Average rainfall is about $275 \mathrm{~cm}$ a year and the average humidity is $82 \%$. Adampur forest is rich in floristic diversity and besides angiosperm it is an ideal habitat for bryophytes and pteridophytes flora ${ }^{(11)}$.

The aim of this study is to enrich the baseline information about pteridophytes for any conservation and management programmem. Documentation of pteridophytes of this forest will help to initiate an updated enriched data base of pteridophytes of Bangladesh.

\section{Materials and Methods}

The present study is a primary documentation of the pteridophyte species of Adampur forest and based on the specimens collected through field exploration. The plant specimens were collected during field visits in the forest trails and hillocks. Field photographs were taken by using Digital camera (Cannon DSLR 600D). The collected plant samples were processed in laboratory for the preparation of voucher specimens. Collected specimens were critically studied and identified by consulting Beddome ${ }^{(12)}$, Clarke(13), Holttum( ${ }^{(14)}$, Dixit(15), Siddiqui etal.(5) and Smitinand and Larsen ${ }^{(16,17)}$. The identified specimens were also compared with the specimens deposited at the 
Bangladesh National Herbarium and Dhaka University Salar Khan Herbarium. The specimens have been preserved at the Department of Botany, Dhaka University. The genera and species under each family have been arranged alphabetically. Valid name, full original citation, important synonym (where available), local name, crisp description and citation of the specimen examined have been furnished under each species.

\section{Results}

A total of 17 pteridophyte species were recorded from Adampur forest of Moulvibazar district. The species are listed in alphabetical order with their family names and synonyms, English name, local name followed by short taxonomic description and citation of the specimen examined.

1. Adiantum capillus-veneris L., Sp. Pl. 2: 1096 (1753). (Adiantaceae).

Synonyms: Adiantum coriandrifolium (1778).

English name: Maiden Hair Fern

Local name: Biddyapata

Description: A drooping, delicate, tufted terrestrial fern with clustered fronds on wiry black stems. It spreads by means of short, creeping rhizomes, covered in small brown scales, which sometimes appear reddish-brown or golden. The fronds are arching and hairless, occasionally with a bluish-green or waxy (glaucous) tinge to the normally pale green leaves, which are pinnate, with individual leaflets often lobed or toothed along the margins.

Specimen examined: Adampur Forest, Rajkandi Bit, 18.11.2016, Nadra, 45.

2. Adiantum peruvianum Klotzch., Linn. 18: 555 (1844). (Adiantaceae).

Synonym: Not known

English name: Silver dollar fern

Local name: Biddyapata

Description: The rhizome is stout and short creeping, densely covered with narrow brown scales and bearing a tuft of fronds. The fronds are triangular in shape, bipinnate to tripinnate. The stipe and rachis are black and shiny, with the base of the former sparsely covered with scales.

Specimen examined: Adampur Forest, Rajkandi Bit, 18.11.2016, Nadra, 62.

3. Adiantum venustum D. Don, Prod. Fl. Nepal 17 (1825). (Adiantaceae).

Synonym: Adiantum microphyllum Roxb. (1844)

English name: Maiden hair fern

Local name: Biddyapata 
Description: This species of Maiden hair fern has a delicate appearance, with black stems holding very small leaves of soft green colour. These are creeping ferns with thin and densely clothed rhizome. Lamina is tri-quadri-pinnate, deltoid-ovate shaped. Dark brown stipe is very firm and wire-like. Pinnae alternate, pinnules loosely arranged.

Specimen examined: Adampur Forest, Rajkandi Bit, 18.11.2016, Nadra, 40.

4. Blechnum orientale L. Sp. Pl. 2: 1077 (1753). (Blechnaceae).

Synonym: Blechnum javanicum Blume (1828)

English name: Not known

Local name: Not known

Description: The plant has erect rhizome with thick and densely covered with narrow, dark brown scales. The fronds are simply pinnate. Pinnae are linear, entire or dentate. The fertile fronds are similar to the sterile or with narrower pinnae. Sori are on the underside of the pinnae, linear and aligned to the midrib. The indusia are narrow and open towards the midrib.

Specimen examined: Adampur Forest, Rajkandi Bit, 18.11.2016, Nadra, 50.

5. Christella appendiculata (Prestl) Holtt. in Kew Bull. 31(2): 311 (1977). (Thelypteridaceae)

Synonym: Nephrodium appendiculatum Presl (1851)

English name: Fern

Local name: Bish Dhekia

Description: Long creeping rhizome with pale reddish stipe. Fronds $30-70 \mathrm{~cm}$ long with 30 pairs of pinnae,10-12 pairs of veins, hairy, sori medial, divergent, indusia small.

Specimen examined: Adampur Forest, Rajkandi Bit, 18.11.2016, Nadra, 57.

6. Lycopodium cernuum L., Sp. Pl. 2: 1103 (1753). (Lycopodiaceae).

Synonym: Lycopodiella cernua (L.) Pic. Serm. (1968).

English name: Staghorn Clubmoss

Local name: Fern

Description: An erect fern with aerial shoots, glabrous, dichotomously branched with well-differentiated lateral branchlets much branched. Leaves of aerial shoots spirally arranged, lateral branches ascending, dichotomously branched with well-differentiated lateral branchlets much branched, pubescent or glabrous. Strobilus solitary, terminal on small branches, often pendulous when mature, pale yellow. Sporangia enclosed.

Specimen examined: Adampur Forest, Rajkandi Bit, 18.11.2016, Nadra, 61. 
7. Lygodium giganteum Tagawa et Iwastsuki in Acta Phytotax. Geobot. 22(3): 97, f.1 (1967). (Lygodiaceae ).

Synonym: Not known

English name: Climbing fern

Local name: Lata Dhekia

Description: This twinning fern has very short creeping rhizome. Fronds are close together and the apex and bases of stipes are covered with dense dark brown hairs. Climbing large fronds, densely pubescent throughout, very narrowly winged.

Specimen examined: Adampur Forest, Rajkandi Bit, 18.11.2016, Nadra, 59.

8. Lygodium flexuosum (L.) Sw. in Schrad. J. Bot. 1800(2): 106(1801). (Lygodiaceae).

Synonym: Ophiglossum flexuosum L. (1753)

English name: Climbing Fern

Local name: Lata dhekia

Description: Perennial climbing fern with short creeping rhizome covered with roots or hair. Juvenile fronds once or twice dichotomously branched, bearing a single leaflet. Rachis slightly hairy, flattened on one side, narrowly winged. Sterile pinnules sometimes fused basally and palmately-lobed, membranous, glabrous or sparsely hairy. Fertile pinnules similar in length or shorter than sterile ones.

Specimen examined: Adampur Forest, Rajkandi Bit, 18.11.2016, Nadra, 58.

9. Microlepia strigosa (Thunb.) Presl, Epim. Bot.: 95(1851). (Dennstaedtiaceae).

Synonym: Trichomanes strigosum Thunb. (1784)

English name: Lacy fern

Local name: Fita Dhekia

Description: Terrestrial plant with creeping rhizome covered with dark brown, uni or multiseriate hairs. Hairy elongated stipes, lanceolate long fronds with bipinnae. Sori submarginal, indusia cup shaped, crenate or fimbricate during maturation.

Specimen examined: Adampur Forest, Rajkandi Bit, 18.11.2016, Nadra, 51.

10. Pronephrium nudatum (Roxb.) Holttum, Blumea 20: 111 (1972). (Thelypteridaceae)

Synonym: Nephrodium moulmeinense Beddome (1876).

English name: Fern

Local name: Dhekia

Description: This fern has creeping strong woody rhizomes covered with lanceolate scales. Rhizomes strong, creeping, woody, dark brown, with sparse broadly lanceolate scales. Fronds remote; stipes bases with brown scales. Lamina herbaceous when dry, green or grayish green. 

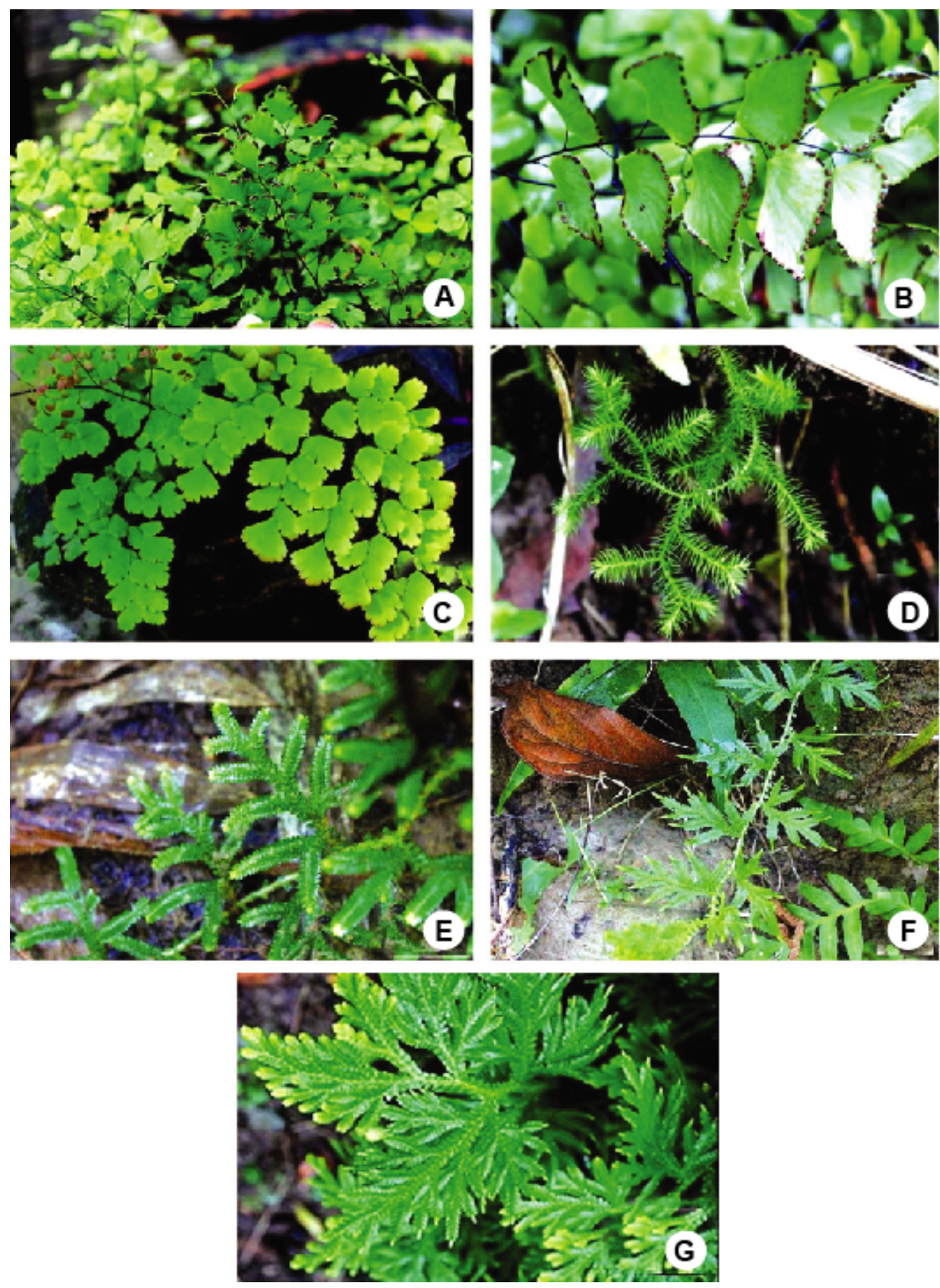

Fig. 1. Pteridophytes of Adampur forest. A. Adiantum capillusveneris; B. Adiantum peruvianum; C. Adiantum venustum; D. Lycopodium cernuum; E. Selaginella tenuifolia; F. Selaginella semicordata; G. Selaginella rependra. 

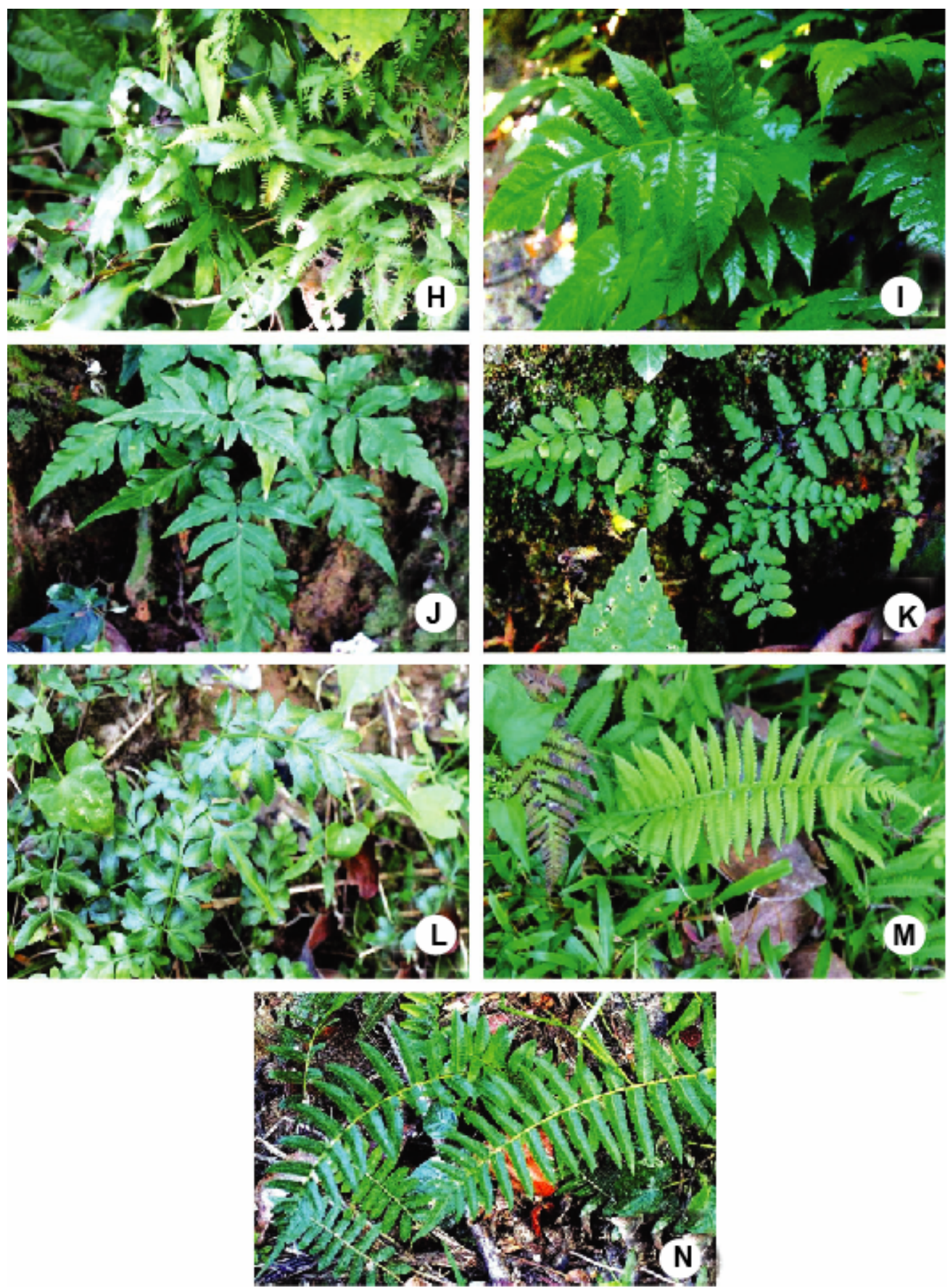

Fig. 2. Pteridophytes of Adampur forest. H. Lygodium flexuosum; I. Tectaria paradoxa; J. Tectaria polymorpha; K. Microlepia strigosa; L. Pteris ensiformis. M. Christella appendiculata; N. Pronephrium nudatum. 
Specimen examined: Adampur Forest, Rajkandi Bit, 18.11.2016, Nadra, 56.

11. Pteris ensiformis Burm. F., Fl. Ind.: 230 (1768). (Pteridaceae).

Synonym: Pteris ensiformis Wall. (1828).

English name: Fern

Local name: Dhekia

Description: A very attractive clump-forming fern with spectacular fronds that display narrow leaflets banded in silvery white throughout the midsections and radiate towards the contrasting dark green. Hence, commonly known as Silver Lace Fern for its lovely lacelike textures. Dainty fern with feathery, variegated fronds. Fronds are bipinnate to tripinnate and arranged on their slender and variable stems of medium green, which are erect in young stage and become pendulous with age. The sori are found on the underside of the leaflets.

Specimen examined: Adampur Forest, Rajkandi Bit, 18.11.2016, Nadra, 60.

12. Pteris vittata L., Sp. Pl. 2 : 1074 (1753). (Pteridaceae).

Synonym: Pteris longifolia Auct. Quoad. Asiat. Bedd. (1883).

English name: Chinese ladder brake

Local name: Dhekia

Description: Dark green fronds are pinnate, with pairs of pinnae lining a single axis. The fronds are odd pinnate, with the terminal pinna longer than the adjacent pinna. Stipes measuring about $20 \mathrm{~cm}$ long, fern blade measuring about $30-50 \mathrm{~cm}$ long.

Sporangia line both edges of each pinna. The sporangia are red with yellow spores.

Specimen examined: Adampur Forest, Rajkandi Bit, 18.11.2016, Nadra, 65.

13. Selaginella rependra (Desv.) Spring in Gaudich. Voy Bonite Bot. 1: 329 (1846). (Selaginellaceae).

Synonyms: Lycopodium repandrum Desv. ex Poir (1814), Lycopodium semicordatum Wall. (1828). Selaginella suberecta Bak. (1884)

English name: Not known

Local name: Not known

Description: Main stem is erect with rhizophores bearing leafy branches borne almost at the base. Dimorphous leaves at the base of the stem, lateral leaves are contiguously spreaded. Strobili borne on the ends and sides of leafy branches, uniform sporophylls are lanceolate-acuminate and margin denticulate.

Specimen examined: Adampur Forest, Rajkandi Bit, 18.11.2016, Nadra, 63. 
14. Selaginella tenuifolia Spring, Mem. Acad. Sci. Belg. 24(2): 253 (1850).

(Selaginellaceae).

Synonyms: Not known

English name: Not known

Local name: Not known

Description: Plants have delicate erect soft stem with prominent rhizome. Leaves are anisosporophyllous throughout the stem.

Specimen examined: Adampur Forest, Rajkandi Bit, 18.11.2016, Nadra, 54.

15. Selaginella semicordata (Wall. ex Hook. \& Grev.) Spring, Mart. Fl. Bras. 1(2): 122 (1840). (Selaginellaceae).

Synonyms: Lycopodium semicordatum Wall. ex. Hook \& Grev. (1831)

English name: Not known

Local name: Not known

Description: The main stem of the plant is prostrate with profuse rooting. Straw coloured thick rhizophores with densely compound branchlets and contiguously spreaded lateral branches. Strobili square and sprophylls are uniform ovate-acute.

Specimen examined: Adampur Forest, Rajkandi Bit, 18.11.2016, Nadra, 64.

16. Tectaria paradoxa(Fée) Sledge, Kew Bull. 27(3): 413 (1972). (Dryopteridaceae)

Synonyms: Nephrodium membranifolium Presl (1825)

English name: Wild fern

Local name: Jungli fern

Description: Terrestrial herb with erect rhizome. Fronds simple or bipinnate. Stipe scaly beneath, glabrous, polished above, grooved. Pinnule lanceolate, long-acuminate in outline, lobed more than half way to the costa. Rachis grooved above and glabrous.

Specimen examined: Adampur Forest, Rajkandi Bit, 18.11.2016, Nadra, 55.

17. Tectaria polymorpha (Wall. ex Hook.) Copel., Phillip J. Sci. 2 Bot.: 413(1907). (Dryopteridaceae)

Synonym: Nephrodium polymorphum Bak. (1867)

English name: Wild fern

Local name: Jungli fern

Description: Terrestrial ferns having erect rhizome. Fronds clustered. Fertile fronds are comparatively tall, slightly narrowed. Lamina simple or trifurcate to odd-pinnate. The shape of the lamina varies from simple or ternate to odd-pinnate.

Specimen examined: Adampur Forest, Rajkandi Bit, 18.11.2016, Nadra, 53. 


\section{Acknowledgements}

Author (NT) is thankful to Ministry of Science and Technology, Govt. of Bangladesh for the financial assistance. Special thanks are due to the Forest Department for their cooperation. She is indebted to Bangladesh National Herbarium (DACB) for permitting her to consult their libraries and herbarium. She is really thankful to Prof. Dr. Md. Oliur Rahman for his insightful comments and suggestions for essential editing of the manuscript. Finally yet importantly, Prof. Dr. Mostafa Kamal Pasha for his kind inputs about identification of species. She wishes to express her gratitude to Sarder Nasir Uddin from DACB for his kind co-operation. The author is thankful to Sumaya Parveen and Hafizur Ruman for their cordial assistance during field visits.

\section{References}

1. Dixit RD 2000. Conspectus of pteridophytic diversity in India. Indian Fern J. 17: 77-91.

2. Dudani S, MDS Chandran and TV Ramachandra 2012. Pteridophytes of Western Ghats. Biodiversity Documentation and Taxonomy. Narendra Publishing House. pp. 343-351.

3. Dudani SN, MK Mahesh, MDS Chandran and TV Ramchandra 2014. Pteridophyte diversity in wet evergreen forests of Sakleshpur in Central Western Ghats. Indian J. Plant Sci. 3: 28-39.

4. https://www.google.com/Fen.banglapedia.org

5. Siddiqui KU, MA Islam, ZU Ahmed, ZNT Begum, MA Hassan, M Khondker, MM Rahman, SMH Kabir, M Ahmed, ATA Ahmed, AKT Rahman and and EU Haque (Eds) 2007. Encyclopedia of Flora and Fauna of Bangladesh, Vol. 5. Asiatic Society of Bangladesh, Dhaka. pp. 195-335.

6. Uddin MG, MM Mirza and MK Pasha 1998. The medicinal uses of pteridophytes of Bangladesh. Bangladesh J. Plant Taxon. 5(2): 29-41.

7. Uddin SB, MA Rahman, MG Uddin and MK Pasha 2008. Ethno-botanical uses of pteridophyte from Chittagong Hill Tracts of Bangladesh. Nepal J. Plant Sci. 2(1): 89-93.

8. Sarker SK and ABME Hossain 2009. Pteridophytes of greater Mymensingh district of Bangladesh used as vegetables and medicines. Bangladesh J. Plant Taxon. 16(1): 47-56.

9. Hadiuzzaman S and M Khondker 1993. Salvinia auriculata Aublet - A new record of Pteridophyte from Bangladesh. Bangladesh J. Bot. 22: 229-231.

10. http://www.banglapedia.org/Index.php?title=Forest_and_Forestry.

11. Rahman ST 2011. Tour Report: Climatic and socio-economic change of Adampur, Kamalganj. Department of Geography and Environment, Shahjalal University of Science and Technology. pp. 2-4.

12. Beddome RH 1883 (Indian reprint 1976). A Handbook to the Ferns of British India, Ceylon and Malaya Peninsula.Thacker, Spink \& Co. Calcutta. pp. 1-300.

13. Clarke CB 1880 (Indian reprint 1973). A Review of the Ferns of Northern India. Trans. Linn. Soc. London Bot. 1: 425-611.

14. Holttum RE 1968. A Revised Flora of Malaya. Fern of Malaya 2. Singapore Govt. Printing Office, Singapore. pp. 1-653. 
15. Dixit RD 1984. A Census of the Indian Pteridophytes. Bot. Surv. India. Dept. Env. pp. 1-177.

16. Smitinand $\mathrm{T}$ and K Larsen (Eds) 1975. Flora of Thailand, Vol. 2, Part 3, Applied Scientific Research Corporation of Thailand, Bangkok. pp. 1-280.

17. Smitinand T and K Larsen (Eds) 1989. Flora of Thailand, Vol. 3, Part 4, Forest Herbarium, Royal Forest Department, Bangkok. pp. 1-640.

(Manuscript received on 5 November, 2017; revised on 16 November, 2017) 